Obere Extremität 2020 $15: 137-141$

https://doi.org/10.1007/s11678-020-00573-1

Received: 16 February 2020

Accepted: 16 April 2020

Published online: 8 May 2020

(c) The Author(s) 2020

K. Wegmann - N. Ott · M. Hackl · T. Leschinger · S. Uschok · A. Harbrecht • J. Knifka • L. P. Müller

Faculty of Medicine and University Hospital, Center for Orthopedic and Trauma Surgery, University of Cologne, Cologne, Germany

\title{
Simulation of life-like distal humerus and olecranon fractures in fresh frozen human cadaveric specimens
}

The elbow is an intricate joint due to its complex anatomy and the not yet completely understood biomechanics. Therefore, elbow injuries remain a difficult entity when surgical repair is necessary. A multitude of different ligamentous injuries, fractures and fracture dislocations are known. But treatment protocols are controversial and complications from surgery are not rare. Stiffness, soft tissue problems and iatrogenic nerve injuries are regularly reported $[1,2]$. Hence, as in any other surgical procedure, it is of utmost importance-for the surgeon as well as for the patient-that an adequate level of skill is present when surgery is performed. However, in today's daily clinical practice, adequate surgical training may be impeded by economic burdens [3]. Numerous studies have investigated the positive effects of simulation training on surgical skills [4-7]. Cadaver training is a method to improve surgeons' capabilities that has been known for centuries, and a multitude of studies have been undertaken to improve this branch of professional education [8-11]. As published in previous work, it is possible to generate life-like fractures in human cadaveric specimens $[12,13]$. Our group has several years of experience in performing surgical education courses with pre-fractured specimens in the field of orthopaedic trauma. In our experience, the educational effect of the courses is increased when the musculoskeletal surgeons perform proper reduction manoeuvres and have to fix complex fractures, rather than placing osteosynthetic implants on intact bone. To also gain such benefit for the fixation of complex elbow fractures, it is necessary to have a reliable in-vitro method of fracture production. The present paper investigated positioning and fixation methods as well as impact energy for generating fractures of the olecranon. A necessary prerequisite was that the fracture mechanism would leave the skin and muscle envelope of fresh frozen human cadaveric specimens intact, except for typical accompanying soft tissue injuries.

\section{Methods}

For the present study, 10 fresh frozen human cadaveric upper extremities (5 right and 5 left extremities) were used. The specimens had been checked via fluoroscopy for any relevant pre-existing trauma or significant degeneration of the joints or implants potentially interfering with fracture simulation. Written consent from body donors was available. Approval from the institutional ethics committee was given prior to the study. The mean age of the donated specimens was 72 years (standard deviation [SD] 5.9; minimum 64; maximum 82). The specimens were thawed at room temperature prior to testing.

\section{Specimen preparation, positioning and fracture unit}

The elbow joints were dissected from the rest of the upper extremities by cutting the humeral shaft and the forearm each at mid length with an oscillating saw. By reducing the length of the adjacent bone shafts, the induction of kinetic energy is more easily focused on the desired anatomic area. Thereafter, over a length of $5 \mathrm{~cm}$, the humeral shaft of the specimens was dissected free of any muscle and other soft tissues. Prepared in this way, the humerus was potted in steel cylinders using polymethyl methacrylate (PMMA). An important task during potting is to position the humerus in a vertical direction, to not have an angulation of the induced forces later in the process. The steel cylinders were custom made for the anatomical area and allow stable fixation in the fracture unit with a strong baseplate of $4 \mathrm{~mm}$ steel. The fracture unit is composed of a drop test bench. The concept of the test bench was taken from the initial work of McGinley et al., who created several complex dislocation fractures around the elbow and forearm in cadaveric specimens with an intact soft tissue envelope [14]. The custom-made fracture unit used in the present paper allows compression of cadaveric specimens with the application of a high energetic axial impulse. Therefore, an impact beam is dropped from a height-adjustable crossbeam onto an impactor. The impactor is guided by 


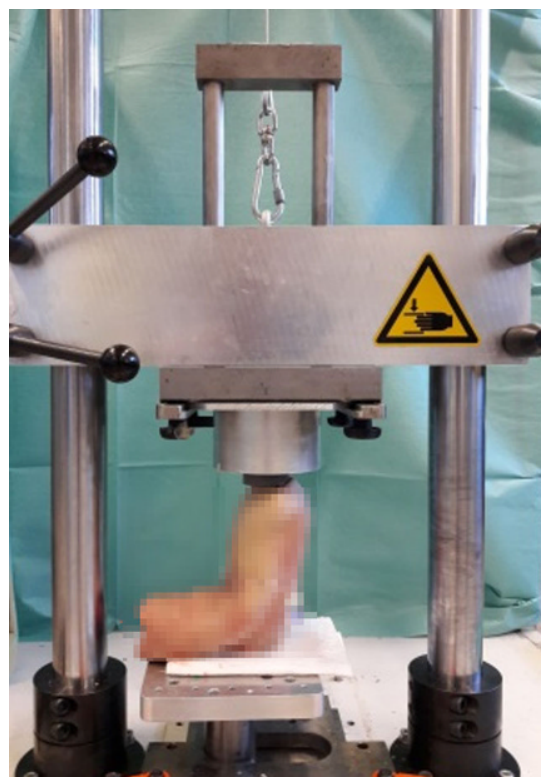

Fig. $1 \Delta$ The specimen is placed in $90^{\circ}$ flexion of the elbow under the impactor, fixed by the cylinder

a second cross beam to help focus the applied energy on the specimen. The specimen is fixed below the impactor with the custom-made steel cylinder, whose base plate is mounted onto the distal end of the impactor. At the bottom of the unit, the specimen can be rested against a ground plate. The length of the impactor allows a maximum degree of shortening of up to $121 \mathrm{~mm}$. There were no dampers or blocks of any kind installed. For stability and even load distribution in the ground, the unit is situated on a $1.5 \times 1.5 \times 0.15 \mathrm{~m}$ steel baseplate. The amount of shortening is set by the applied kinetic energy, which itself is defined by the drop height and the drop weight by the formula $\mathrm{E}=1 / 2 \times \mathrm{m} \times \mathrm{v}^{2}$ $(\mathrm{E}=$ energy, $\mathrm{m}=$ mass, $\mathrm{v}=$ velocity $)$. The weight is adjusted by adding steel bars to the impact beam. The fracture unit allows generation of a maximum kinetic energy of up to 210 Joule (J). Before inducing the fracture, the applied kinetic energy was estimated based on the constitution of the specimen, as specimens vary in bone density and stability. This step is based on experience taken from previous fracture simulations. The weight of the impactor and the height from which it was released were set accordingly.

To achieve fractures of the distal humerus and the olecranon, specimens were placed in $90^{\circ}$ flexion of the el-

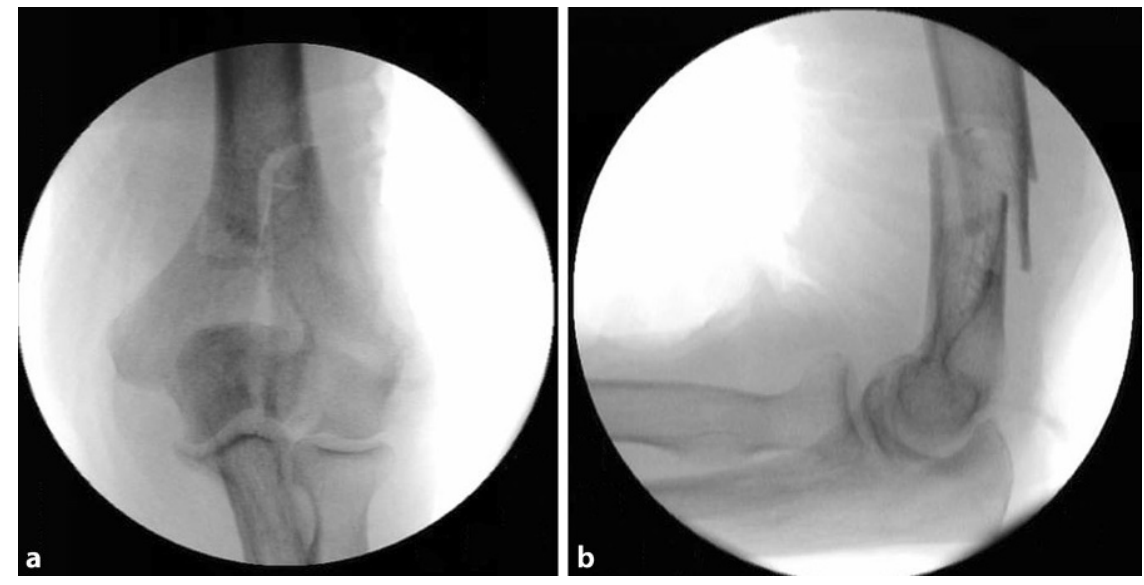

Fig. $2 \Delta$ C3 fracture of the distal humerus according to the Arbeitsgemeinschaft Osteosynthesefragen (AO) classification (a a.p.x-ray, b lateral x-ray)

bow below the impactor (• Fig. 1). The steel plate of the potting cylinders was mounted on the distal end of the impactor in a way that the humeral shaft ended up in a position vertical to the ground plate. As the specimens were positioned with $90^{\circ}$ flexion in the elbow, the ulna came to rest parallel to the ground plate.

Following impaction of the specimens, $\mathrm{x}$-ray images were taken using a mobile C-arm unit (Ziehm Exposcop 8000 Endo; Ziehm, Nuremberg, Germany).

The fractures of the distal humerus were classified on the basis of the available imaging by three experienced trauma surgeons (HA, US, LT) according to the Arbeitsgemeinschaft Osteosynthesefragen/Association for the Study of Internal Fixation (AO/ASIF) fracture classification [15]. For the fractures of the olecranon, the Mayo classification was used [16].

\section{Statistical analysis}

Mean values, SD, and minimum and maximum values were computed as descriptive statistics using software (IBM SPSS Statistics 25; IBM Corp., Armonk, NY, USA). Differences in the applied kinetic energy between olecranon and distal humerus fractures were analysed using a two-sample $t$-test. The level of significance was set at $p \leq 0.05$.

\section{Results}

Of the 10 specimens, 6 showed a fracture of the distal humerus and 4 had an olecranon fracture. The distal humerus fractures were mainly of types $\mathrm{C} 2$ and $\mathrm{C} 3$ (- Fig. 2). The olecranon fractures were mainly assorted to type IIB (• Fig. 3). - Table 1 summarizes the fracture types.

The mean applied energy was $44.4 \mathrm{~J}$ (SD $14.5 \mathrm{~J}$; minimum $32.6 \mathrm{~J}$; maximum $83.2 \mathrm{~J})$. For the group of the distal humerus fractures it was 48.6 J (SD 4.47 J; minimum $32.6 \mathrm{~J}$; maximum $83.2 \mathrm{~J}$ ). For the olecranon fractures it was $40.8 \mathrm{~J}$ (SD $4.4 \mathrm{~J}$; minimum $34.9 \mathrm{~J}$; maximum $44.3 \mathrm{~J})$. No significant difference was observed $(p=0.25)$. All 10 fractures were reviewed by the authors and estimated as adequate for use in surgical training courses for the education of musculoskeletal surgeons.

\section{Discussion}

Based on the present findings, we conclude that simulation of fractures of the distal humerus and the olecranon on fresh frozen human cadaveric specimens with an otherwise intact skin and muscle envelope is possible using an axial impaction unit. To the best of our knowledge, no other published study has investigated the creation of distal humerus and olecranon fractures in this way to date.

The relevance of the study is twofold: On the one hand, we have shown that 
Obere Extremität 2020 · 15:137-141 https://doi.org/10.1007/s11678-020-00573-1

(c) The Author(s) 2020

K. Wegmann · N. Ott · M. Hackl · T. Leschinger · S. Uschok · A. Harbrecht · J. Knifka · L. P. Müller

Simulation of life-like distal humerus and olecranon fractures in fresh frozen human cadaveric specimens

\section{Abstract}

Background. Economic burden and personnel shortages lead to a reduction in the time spent on surgical training of young resident physicians. This underlines the importance of courses for learning and optimizing surgical skills. Particularly for orthopaedic trauma surgery, training on fractured cadaveric specimens has proven highly useful. The present study investigates a method to induce realistic fracture patterns in fresh frozen elbow specimens, leaving the skin and soft tissue envelope intact.

Methods. For fracture simulation, 10 human cadaveric specimens with intact soft tissue envelopes were placed in $90^{\circ}$ flexion in a custom-made high-impact test bench and compressed by an impactor. The fractures were subsequently classified using conventional $\mathrm{x}$-rays.

Results. Of the 10 specimens, 6 could be classified as distal humerus fractures and 4 as olecranon fractures. The fractures of the distal humerus were mainly type $\mathrm{C}$ according to Arbeitsgemeinschaft Osteosynthesefragen (AO) criteria, the olecranon fractures were mainly type IIB according to the Mayo classification. Subsequently, all 10 specimens would have been appropriate for use in musculoskeletal trauma courses.

Conclusion. With the given setup it was possible to induce realistic fracture patterns in fresh frozen cadaveric specimens. The advantage of the presented technique lies in the preservation of soft tissue. With their intact soft tissue envelopes, these pre-fractured preparations could be used in courses to precisely train resident physicians directly on human cadaver preparations. Further research should focus on finding reliable predictors to improve the precision of fracture induction in specimens.

\section{Keywords}

Humeral fracture - Elbow - Trauma - Internship and residency - Education, professional

\section{Simulation von realistischen distalen Humerus- sowie Olekranonfrakturen an eingefrorenen humanen Leichenpräparaten}

\section{Zusammenfassung}

Hintergrund. Die betriebswirtschaftlichen Entwicklungen sowie die Personalveränderungen im medizinischen Bereich führen zu einer Verkürzung der chirurgischen Ausbildung von jungen Assistenzärzten. Dies unterstreicht die Notwendigkeit von Kursen zum Erlangen sowie zur Optimierung von chirurgischen Fähigkeiten. Vor allem im Bereich der Unfallchirurgie hat sich das Training an vorfrakturierten Präparaten als äußert hilfreich erwiesen. Das Ziel dieser Studie ist es, eine Methode zur realistischen Simulation von distalen Humerus- sowie Olekranonfrakturen an gefrorenen Ellbogenpräparaten mit Intaktbleiben von Haut und Weichteilen zu untersuchen.

Methoden. Zur Fraktursimulation wurden 10 humane Leichenpräparate mit intakten sowie geschlossenen Weichteilen in $90^{\circ}$
Flexion des Ellenbogengelenks in die Frakturmaschine eingespannt und durch den Impaktor komprimiert. Anschließend wurden die frakturierten Präparate anhand von konventionellen Röntgenaufnahmen klassifiziert.

Ergebnisse. Von den 10 humanen Leichenpräparaten konnten 6 als distale Humerusfraktur und 4 als Olekranonfraktur klassifiziert werden. Analog zur Klassifikation gemäß Arbeitsgemeinschaft Osteosynthesefragen (AO) handelte es sich bei den distalen Humerusfrakturen vorwiegend um Typ-C-Frakturen, die Olekranonfakturen wurden nach der Mayo-Klassifikation als Typ IIB klassifiziert. Alle Präparate konnten anschließend für unfallchirurgische Kurssysteme erfolgreich genutzt werden.
Schlussfolgerung. Das vorgestellte Konzept zur Fraktursimulation an gefrorenen humanen Leichenpräparaten war in der Lage, realistische distale Humerus- sowie Olekranonfrakturen zu generieren. Der Vorteil des vorgestellten Verfahrens liegt v. a. in der Schonung der Weichteile. Bei intakten Weichteilen konnten die vorfrakturierten Präparate vollständig in dem Kurssystem verwendet werden. Dies ermöglicht die präzise Ausbildung von Assistenzärzten direkt am humanen Leichenpräparat. Zur Verbesserung der Präzision der Fraktursimulation sollten weitere Studien auf der Analyse von möglichen Einflussfaktoren basieren.

Schlüsselwörter

Humerusfraktur · Ellbogen · Trauma .

Facharztausbildung · Berufliche Weiterbildung typical fractures of the distal humerus and olecranon seem to occur by acute compression of the articular surfaces of the greater sigmoid notch of the olecranon and the trochlea. Secondly, we generated specimens that could be put to good use in surgical training courses. The achieved fractures had adequate complexity and configuration to educate even experienced surgeons. Attendees would likely benefit from learning repositioning manoeuvres in realistic fractures, without being under time pressure or having to fear complications [13]. The cadaver setting also allows the attendees to dissect anatomy around the fracture area more extensively than in clinical surgery, allowing appreciation of the intricate neurovascular anatomy around the elbow. Also, planning the approach is an important step in training, as the elbow allows a multitude of different surgical approaches, offering advantages and disadvantages according to the pathology present. The intact soft tissues around the fractured joint enable the course attendee to realistically plan the desired approach and learn about the anatomy surrounding the course of the approach. The course setting offers the possibility of having an expert instructor alongside, who can teach optimally in such a scenario. 


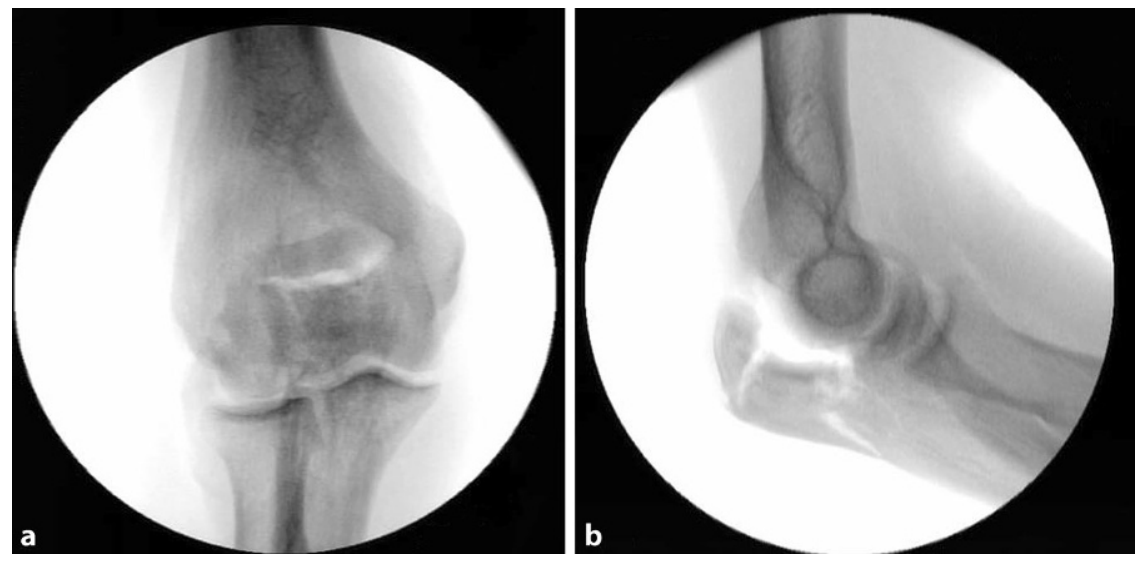

Fig. $3 \Delta$ Type IIB fracture of the olecranon according to the Mayo classification (a a.p.x-ray, b lateral $\mathrm{x}$-ray)

It remains debateable whether realistic fracture scenarios can be recreated with the given setup. Our fracture unit only allows one-dimensional load induction, rotational motion is not possible. Previous work has been published on the creation of life-like fractures in cadaveric specimens with an intact soft tissue envelope [17-19]. As early as 1908, Lilienfeld elaborated on distal radius fractures [20]. He used cadaveric specimens and manual force to apply load on hyperextended wrist joints. Additionally, Lewis undertook experiments to simulate Colles fractures at the distal radius in 1950 [21]. Following the work of these authors, Pechlaner et al. created fractures of the distal radius in cadaveric fresh frozen specimens with an intact soft tissue envelope using a material testing machine [22]. According to their publications, the authors were able to generate typical fracture patterns with mostly monoaxial impaction, as in the present study on the elbow joint. McGinley investigated the development of dislocation fractures of the elbow and forearm [14]. He also successfully simulated radial head fractures, both-bone fractures of the forearm and Essex-Lopresti injuries with monoaxial impaction. Hence, we believe that an adequate array of elbow fractures can be achieved by using the present fracture unit. An object of future research could be to evaluate to which extent the induction of varus and valgus forces assists in the generation of further pathologies, like terrible triad injuries and posteromedial rotational instability of the elbow.
After analysis of the fractures of the distal humerus, the olecranon seemed to have to split the humerus and driven its joint block in between the medial and lateral columns, leading to the typical fragmentation. At the olecranon, analysis of the fracture mechanism rendered it likely that the trochlea of the humerus acted as a stamp, pushing the central joint segment of the greater sigmoid notch through the cancellous bone within the olecranon, leading to its displacement and finally to fracture of the dorsal cortex. The achieved fractures of the olecranon showed a typical fracture pattern in most of the specimens. However, in one specimen, the fragmentation was too extensive. The dorsal cortex of the olecranon at the level of the bare area was highly comminuted and reconstruction would not have been possible. Although such fragmentation can be seen in live cases, it is not of beneficial use for educational courses. In the present configuration, it was not possible to predict whether the olecranon or the distal humerus fractured. Identification of the factors defining the actual fracture in the used position should be subjected to future research.

Muscle forces did not seem to have a relevant influence on the generation of the fractures in the present setting. In general, the fracture configuration resembled patterns from daily clinical practice, even though the specimens did not have simulated muscle tension nor applied pull on the tendons surrounding the elbow joint. In 2002, the authors' group
Table 1 Different fracture types of the distal humerus and the olecranon in the specimens

\begin{tabular}{ll}
$\begin{array}{l}\text { Distal humerus } \\
\text { AO classification }\end{array}$ & $\begin{array}{l}\text { Olecranon } \\
\text { Mayo classification }\end{array}$ \\
\hline C3 & IIIB \\
B1 & IIB \\
C2 & IIB \\
\hline B2 & \\
C3 & \\
C3 & \\
\hline $\begin{array}{l}\text { AO Arbeitsgemeinschaft Osteosynthese- } \\
\text { fragen }\end{array}$ \\
\hline
\end{tabular}

published on the chronological order of the development of the injury complex of Essex-Lopresti lesions [23]. In the latter study, formalin-embalmed forearm specimens were mounted in a similar fracture unit. With an axial high-energetic impact, Essex-Lopresti injury configurations could be created. To be able to document the chronological order of events, the specimens were dissected free from skin, subcutaneous fat and muscles. The relevant stabilizing soft tissues such as joint capsules, collateral ligaments and the interosseous membrane were left intact. However, also under these in-vitro settings could Essex-Lopresti lesions be created. Therefore, the influence of muscle pull may not be essential in the invitro setting. Future research could address this question and induce fractures in specimens with and without muscle pull to look for differences in the outcome.

When using body donors for research and education, it is of utmost importance to do this in accordance with ethical standards. We believe that for courses covering musculoskeletal trauma, the use of pre-fractured specimens offers an enhancement of the teaching effect that these specimens have for attendees. With such a potential positive effect, we may be able to put the generous gift of the body donors to even better use. Thus, future research should be undertaken to facilitate the availability of pre-fractured specimens for surgical courses. Technical and financial aspects will probably have to be tackled. 


\section{Conclusion}

The present findings demonstrate that it is possible to simulate distal humerus and olecranon fractures with an intact soft tissue envelope on fresh frozen human cadaveric specimens using an axial impaction unit. To allow for independent education of young as well as experienced surgeons in the future, establishment of respective training centres could represent an object of collaboration for expert societies and scientific associations.

\section{Corresponding address

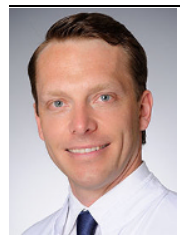 \\ PD Dr. K. Wegmann \\ Faculty of Medicine and University Hospital, Center for Orthopedic and Trauma Surgery, University of Cologne Kerpener Str. 62, 50937 Cologne, Germany kilian.wegmann@uk-koeln.de}

Funding. Open Access funding provided by Projekt DEAL.

\section{Compliance with ethical guidelines}

Conflict of interest. K. Wegmann, N. Ott, M. Hackl, T. Leschinger, S. Uschok, A. Harbrecht, J. Knifka, and L.P. Müller declare that they have no competing interests.

Approval from the institutional ethics committee was given prior to the study. Written consent from body donors was available.

Open Access. This article is licensed under a Creative Commons Attribution 4.0 International License, which permits use, sharing, adaptation, distribution and reproduction in any medium or format, as long as you give appropriate credit to the original author(s) and the source, provide a link to the Creative Commons licence, and indicate if changes were made. The images or other third party material in this article are included in the article's Creative Commons licence, unless indicated otherwise in a credit line to the material. If material is not included in the article's Creative Commons licence and your intended use is not permitted by statutory regulation or exceeds the permitted use, you will need to obtain permission directly from the copyright holder. To view a copy of this licence, visit http://creativecommons.org/licenses/by/4.0/.

\section{References}

1. van Rheenen $T A$, van den Bekerom MP, Eygendaal $D$ (2015) The incidence of neurologic complications and associated risk factors in elbow surgery: an analysis of 2759 cases. J Shoulder Elb Surg 24(12):1991-1997

2. Zhang D, Nazarian A, Rodriguez EK (2020) Posttraumatic elbow stiffness: pathogenesis and current treatments. ShoulderElb 12(1):38-45

3. Kalun P, Wagner N, Yan J, Nousiainen MT, Sonnadara RR (2018) Surgical simulation training in orthopedics: current insights. Adv Med Educ Pract 9:125-131

4. Causer J, Vickers JN, Snelgrove R, Arsenault G, Harvey A (2014) Performing under pressure: quiet eye training improves surgical knot-tying performance. Surgery 156(5):1089-1096

5. Hilska M, Roberts PJ, Kossi J, Paajanen H, Collan Y, Laato M (2004) The influence of training level and surgical experience on survival in colorectal cancer. Langenbecks Arch Surg 389(6):524-531

6. Ind TE, Shelton JC, Shepherd JH (2001) Influence of training on reliability of surgical knots. BJOG 108(10):1013-1016

7. Ribeiro IB, Ngu JMC, Lam BK, Edwards RA (2018) Simulation-based skill training for trainees in cardiac surgery: a systematic review. Ann Thorac Surg 105(3):972-982

8. Bellier A, Fournier J, Faure Q, Snyman S, Mirallie C Chaffanjon P (2019) Development of cadaver perfusion models for surgical training: an experimental study. Surg Radiol Anat 41(10):1217-1224

9. Hayashi S, Naito M, Kawata S, Qu N, Hatayama N, Hirai $S$ et al (2016) History and future of human cadaver preservation for surgical training: from formalin to saturated salt solution method. Anat Scilnt 91(1):1-7

10. Held JM, McLendon RB, McEvoy CS, Polk TM (2019) $A$ reusable perfused human cadaver model for surgical training: an initial proof of concept study. Mil Med 184(Suppl 1):43-47

11. van Renterghem K, Ghazi A (2019) 3D pelvic cadaver model: a novel approach to surgical training for penile implant surgery. Int J Impot Res. https://doi.org/10.1038/s41443-019-0211-2

12. Wegmann K, Harbrecht A, Hackl M, Uschok S, Leschinger T, Muller LP (2019) Inducing lifelike distal radius fractures in human cadaveric specimens: a tool for enhanced surgical training. Arch Orthop Trauma Surg 140:425-432

13. Wegmann K, Rausch V, Burkhart KJ, Hackl M, Leschinger T, Muller L (2019) Advanced surgical trauma care course-evaluation of a fracture simulation course concept with intact soft tissue. ZOrthop Unfall. https://doi.org/10.1055/a-09838322

14. McGinley JC, Hopgood BC, Gaughan JP, Sadeghipour K, Kozin SH (2003) Forearm and elbow injury: the influence of rotational position. JBone Joint Surg Am 85(12):2403-2409

15. E. MM (1991) The principle of the classification. In: Allgöwer M (ed) Manual of internal fixation: techniques recommended by the AO-ASIF group. Springer, New York, p 118

16. Sullivan CW, Desai K (2019) Classifications in brief: Mayo classification of olecranon fractures. Clin Orthop Relat Res 477(4):908-910

17. Amis AA, Miller JH (1995) The mechanisms of elbow fractures: an investigation using impact tests in vitro. Injury 26(3):163-168

18. Lauge-Hansen N (1950) Fractures of the ankle. II. Combined experimental-surgical and experi- mental-roentgenologic investigations. Arch Surg 60(5):957-985

19. Masouros SD, Newell N, Ramasamy A, Bonner TJ, West AT, Hill AM et al (2013) Design of a traumatic injury simulator for assessing lower limb response to high loading rates. Ann Biomed Eng 41(9):1957-1967

20. Lilienfeld A (1908) Über die Erzeugung der typischen Verletzungen der Handwurzelknochen und des Radiusbruches auf indirektem Wege an derLeicheundihreEntstehungsart, erläutert durch den Mechanismus der Handgelenksbewegungen. ZOrthop Chir 20:437-454

21. Lewis RM (1950) Colles fracture-causative mechanism. Surgery 27:427-436

22. Pechlaner S, Kathrein A, Gabl M, Lutz M, Angermann P, Zimmermann R et al (2002) Distal radius fractures and concomitant lesions. Experimental studies concerning the pathomechanism. Handchir Mikrochir Plast Chir 34(3):150-157

23. Wegmann K (2014) Sequence of the Essex-Lopresti lesion-a high-speed video documentation and kinematic analysis. Acta Orthop 85(5):545-546 